\title{
PENGARUH STRUKTUR GOOD CORPORATE GOVERNANCE DAN KINERJA LINGKUNGAN TERHADAP PENGUNGKAPAN CORPORATE SOCIAL RESPONSIBILITY
}

(Studi Pada Perusahaan Manufaktur di Bursa Efek Indonesia Periode 2011-2015)

\author{
Anna Sukasih ${ }^{1}$ \\ *Akuntansi, Ekonomi dan Bisnis, Universitas Muhammadiyah Surakarta \\ *sukasih.anna@gmail.com ${ }^{l}$ \\ Eko Sugiyanto $^{2}$ \\ *Akuntansi, Ekonomi dan Bisnis, Universitas Muhammadiyah Surakarta \\ *ekosugiyanto_01@yahoo.com ${ }^{2}$
}

\begin{abstract}
The aim of this research is to analysis the influence of managerial ownership, institutional ownership, audit committee, size of board of commissioners, and environmental performance on the disclosure of Corporate Social Responsibility (CSR). The measurement of corporate social responsibility based on the Global Reporting Initiative disclosure index (GRI) 2013 as seen from the company's annual report. The population of this research is manufacture companies listed in Indonesia Stock Exchange (IDK) 2011-2015. Research sampling used purposive sampling technique and found 24 companies, with 5 years of observation. So, the total sample studied was 120. The collected data was analysis using classic assumption test then do hypothesis test. Testing the hypothesis in this study using multiple regression analysis with $t$-test, $f$, and coefficient of determination. The result indicate that managerial ownership and institutional ownership have a significant influence on the disclosure of Corporate Social Responsibility (CSR). Meanwhile, audit committee, size of board of commissioners, and environmental performance don't have significant influence on the disclosure of Corporate Social Responsibility (CSR).
\end{abstract}

Keywords: Corporate Social Responsibility (CSR), managerial ownership, institutional ownership, audit committee, size of board of commissioners, and environmental performance.

\section{Pendahuluan}

Dewasa ini tuntutan terhadap perusahaan semakin besar karena selain dituntut untuk mengejar profit, perusahaan juga harus memerhatikan dan terlibat dalam pemenuhan kesejahteraan masyarakat serta turut aktif berkontribusi dalam menjaga kelestarian lingkungan (Wardhani dan Sugiharto, 2013). Pada perusahaan bisnis yang bergerak di bidang pemanfaatan sumber daya alam, seringkali perusahaan mengabaikan dampak sosial dan lingkungan yang terjadi atas tindakan ekonomi yang dilakukan dimana tindakan tersebut dapat menyebabkan kerusakan lingkungan, misalnya penggundulan hutan, polusi udara, pencemaran air karena limbah pabrik, dan lain sebagainya. Atas keresahan tersebut masyarakat menuntut perusahaan untuk mengubah perilakunya dengan melakukan pengungkapan tanggung jawab sosial dan lingkungan.

Riset Akuntansi dan Keuangan Indonesia, 2(2), 2017
Tujuan pengungkapan (disclosure) adalah menyajikan informasi yang dipandang perlu untuk mencapai tujuan pelaporan keuangan dan melayani kebutuhan berbagai pihak yang mempunyai kepentingan berbeda-beda (Suwardjono, 2005). Di Indonesia praktik pengungkapan tanggung jawab sosial diatur oleh Ikatan Akuntan Indonesia (IAI) dalam Pernyataan Standar Akuntansi Keuangan (PSAK) No.1 Paragraf 9, yang menyatakan bahwa "Perusahaan dapat pula menyajikan laporan tambahan seperti laporan mengenai lingkungan hidup dan laporan nilai tambah (value added statement), khususnya bagi industri dimana faktor-faktor lingkungan hidup memegang peranan penting dan bagi industri yang menganggap pegawai sebagai kelompok pengguna laporan yang memegang laporan penting".

Penerapan good corporate governance serta pengungkapan informasi corporate social responsibility merupakan konsep yang diajukan demi 
peningkatan kinerja perusahaan. Apabila konsep ini diterapkan dengan baik maka diharapkan pertumbuhan ekonomi akan terus meningkat seiring dengan transparansi pengelolaan perusahaan yang makin baik dan nantinya menguntungkan banyak pihak. Pada penelitian kali ini, penerapan good corporate governance akan dilihat melalui strukturnya yang diproksikan dengan proporsi kepemilikan manajerial, kepemilikan institusional, komite audit dan ukuran dewan komisaris.

Untuk kinerja lingkungan, semakin baik aktivitas lingkungan yang dilakukan oleh perusahaan akan menyebabkan peningkatan kepercayaan dimata stakeholder. Di Indonesia sendiri, kelestarian lingkungan sudah menjadi kebijakan pemerintah pada setiap periode. Pada TAP MPR No. II/MPR/1998 tentang Garis Besar Haluan Negara (GBHN), dinyatakan: "Kebijakan Sektor Lingkungan Hidup, antara lain, mengenai pembangunan lingkungan hidup diarahkan agar lingkungan hidup tetap berfungsi sebagai pendukung dan penyangga ekosistem kehidupan dan terwujudnya keseimbangan, keselarasan dan keserasian yang dinamis antara sistem ekologi, sosial ekonomi, dan sosial budaya agar dapat menjamin pembangunan nasional yang berkelanjutan" (GBHN, 1998).

\section{Kajian Pustaka dan Pengembangan Hipotesis Teori Keagenan}

Teori agensi menjelaskan hubungan keagenan antara dua pihak dimana satu atau lebih orang (principal) mempekerjakan orang lain (agent) untuk melaksanakan jasa atas nama mereka yang melibatkan pendelegasian wewenang pembuatan keputusan kepada agent (Jensen dan Meckling, 1976). Perbedaan kepentingan antara dua pihak tersebut dapat menimbulkan konflik keagenan. Konflik ini terjadi karena kemungkinan agent tidak bertindak sesuai dengan kepentingan principal. Selain itu, konflik timbul juga dikarenakan adanya ketidakseimbangan informasi yang dimiliki oleh principal dan agent atau sering disebut sebagai asimetri informasi. Ketidakseimbangan atas informasi ini dapat memberikan kesempatan kepada manajer untuk melakukan tindakan opportunis seperti manajemen laba.

\section{Teori Stakeholder}

Stakeholders theory menyatakan bahwa kelangsungan hidup perusahaan tergantung pada dukungan stakeholder yang mempengaruhi atau dapat dipengaruhi oleh aktivitas perusahaan (Ghozali dan Chariri, 2007 dalam Rustiarini, 2011). Setiap stakeholders memiliki hak untuk disediakan informasi mengenai pengaruh stakeholders terhadap organisasi, sekalipun stakeholder memilih untuk tidak menggunakan informasi tersebut ataupun stakeholder tidak memiliki pengaruh secara langsung terhadap keberlangsungan organisasi (Deegan, 2000). Ratnasari dan Andri (2010) menyatakan bahwa salah satu strategi yang digunakan perusahaan untuk menjaga hubungan dengan para stakeholder-nya adalah dengan pengungkapan informasi sosial dan lingkungan.

\section{Teori Legitimasi}

Menurut Deegan (2000:253), teori legitimasi meyakini suatu gagasan bahwa terdapat "kontrak sosial" antara organisasi dengan lingkungan dimana organisasi tersebut beroperasi. Konsep "kontrak sosial" digunakan untuk menunjukkan harapan masyarakat tentang cara yang seharusnya dilakukan organisasi dalam melakukan aktivitas. Harapan masyarakat terhadap perilaku perusahaan dapat bersifat implisit dan eksplisit. Bentuk eksplisit dari kontrak sosial adalah persyaratan legal, sementara bentuk implisitnya adalah harapan masyarakat yang tidak tercantum dalam peraturan legal. Pengungkapan pelaporan sosial dan lingkungan menjadi salah satu cara perusahaan untuk mewujudkan kinerja yang baik kepada masyarakat dan investor. Dengan pengungkapan tersebut, perusahaan akan mendapatkan image dan pengakuan yang baik serta akan memiliki daya tarik dalam penanaman modal atau investor dalam negeri maupun asing.

\section{Corporate Social Responsibility (CSR)}

Pertanggungjawaban sosial perusahaan atau Corporate Social Responsibility (CSR) adalah mekanisme bagi suatu organisasi untuk secara sukerela mengintegrasikan perhatian terhadap lingkungan dan sosial ke dalam operasi utamanya dan kaitannya dengan stakeholder yang melebihi tanggung jawab organisasi di bidang hukum (Darwin, dalam Priantana dan Yustian, 2011). 


\section{Pengungkapan Corporate Social Responsibility (CSR)}

Kata pengungkapan secara umum memiliki arti tidak menutupi atau tidak menyembunyikan. Tujuan pengungkapan adalah menyajikan informasi yang dipandang perlu untuk mencapai tujuan pelaporan keuangan dan melayani kebutuhan berbagai pihak yang mempunyai kepentingan berbeda-beda (Suwardjono, 2005).

\section{Good Corporate Governance (GCG)}

Menurut Cadbury Committee, dalam Forum for Corporate Governance in Indonesia (FCGI) yaitu seperangkat peraturan yang mengatur hubungan antara pemegang saham, pengurus (pengelola) perusahaan, pihak kreditur, pemerintah, karyawan serta para pemegang kepentingan intern dan ekstern lainnya yang berkaitan dengan hak-hak dan kewajiban mereka, atau dengan kata lain suatu sistem yang mengatur dan mengendalikan perusahaan.

\section{Struktur Corporate Governance Kepemilikan Manajerial}

Salah satu struktur kepemilikan saham dalam perusahaan yaitu kepemilikan manajerial. Kepemilikan manajerial adalah kepemilikan saham perusahaan oleh direksi, komisaris, ataupun manajemen perusahaan. Sehingga dengan adanya kepemilikan manajerial pengelola dapat melaksanakan aktivitas perusahaan sesuai dengan kepentingannya.

Menurut Gideon, dalam Rawi (2008) mengatakan bahwa kepemilikan manajerial adalah jumlah kepemilikan saham yang dimiliki oleh pihak manajemen dari jumlah saham yang dikelola oleh perusahaan. Secara khusus kepemilikan manajerial terhadap perusahaan atau yang biasa dikenal dengan istilah Insider Ownership ini didefinisikan sebagai persentase suara yang berkaitan dengan saham dan pilihan yang dimiliki oleh manajer dan direksi suatu perusahaan (Mathiesen, dalam Rawi 2008). Kepentingan manajer selaku pengelola perusahaan akan dapat berbeda dengan kepentingan pemegang saham.

\section{Kepemilikan Institusional}

Institusi merupakan sebuah lembaga yang memiliki kepentingan besar terhadap investasi yang dilakukan termasuk investasi saham (Murwaningsari, 2009). Sehingga biasanya institusi menyerahkan tanggungjawab pada divisi tertentu untuk mengelola investasi perusahaan tersebut. Karena institusi memantau secara profesional perkembangan investasinya maka tingkat pengendalian terhadap tindakan manajemen sangat tinggi sehingga potensi kecurangan dapat ditekan. Kepemilikan institusional merupakan salah satu faktor yang dapat mempengaruhi kinerja perusahaan.

Kepemilikan oleh investor institusional akan mendorong peningkatan pengawasan yang lebih optimal terhadap kinerja manajemen, karena kepemilikan saham mewakili suatu sumber kekuasaan yang dapat digunakan untuk mendukung atau sebaliknya terhadap kinerja manajemen. Investor institusional umumnya merupakan pemegang saham yang cukup besar karena memiliki pendanaan yang besar. Tingkat kepemilikan institusional yang tinggi menimbulkan usaha pengawasan yang lebih besar untuk menghalangi perilaku opportunistic manajer.

\section{Komite Audit}

Komite audit merupakan salah satu komite yang memiliki peran penting dalam corporate governance. Menurut Natalylova (2013) komite audit harus terdiri dari individu-individu yang mandiri dan tidak terlibat dengan tugas sehari-hari dari manajemen yang mengelola perusahaan, dan yang memiliki pengalaman untuk melaksanakan fungsi pengawasan secara efektif. Komite audit adalah komite yang dibentuk oleh dewan komisaris, yang bertugas membantu dewan komisaris dalam melaksanakan tugasnya.

Di Indonesia keberadaan komite audit merupakan sebuah kewajiban, diatur dalam Pedoman Umum Good Corporate Governance (GCG) yang dikeluarkan Komite Nasional Kebijakan Governance (KNKG) 2006: "Bagi perusahaan yang sahamnya tercatat di bursa efek, perusahaan negara, perusahaan daerah, perusahaan yang menghimpun dan mengelola dana masyarakat, perusahaan yang produk dan jasanya digunakan oleh masyarakat luas, serta perusahaan yang memiliki dampak luas terhadap kelestarian lingkungan, sekurang-kurangnya harus membentuk Komite Audit."

\section{Ukuran Dewan Komisaris}

Dewan komisaris merupakan salah satu sturktur yang ada di dalam corporate governance yang berdampak pada corporate social responsibility. Alasannya dewan komisaris dengan integritas yang tinggi dirasa akan meningkatkan CSR Disclosure. Berdasarkan teori agensi, dewan komisaris dianggap sebagai mekanisme pengendalian intern tertinggi yang 
bertanggung jawab untuk memonitor tindakan manajemen puncak.

Dengan wewenang yang dimiliki, dewan komisaris dapat memberikan pengaruh yang cukup kuat untuk menekan manajemen agar mengungkapkan informasi CSR lebih banyak, sehingga dapat dijelaskan bahwa perusahaan yang memiliki ukuran dewan komisaris yang lebih besar akan lebih banyak mengungkapkan CSR. Sebagai wakil dari principal di dalam perusahaan, dewan komisarin dapat mempengaruhi luasnya pengungkapan tanggung jawab social, karena dewan komisaris merupakan pelaksana tertinggi didalam entitas.

\section{Kinerja Lingkungan}

Menurut Suratno, et al (2006) kinerja lingkungan adalah kinerja perusahaan dalam menciptakan lingkungan yang baik (green). Kinerja lingkungan diukur dari prestasi perusahaan mengikuti Program Penilaian Peringkat Kinerja Perusahaan dalam Pengelolaan Lingkungan Hidup (PROPER). Program ini merupakan salah satu upaya yang dilakukan oleh Kementrian Lingkungan Hidup (KLH) untuk mendorong penataan perusahaan dalam pengelolaan hidup. PROPER diumumkan secara rutin kepada masyarakat, sehingga perusahaan yang dinilai akan mendapat insentif maupun disinsentif reputasi, tergantung pada tingkat ketaatannya. Tujuan diadakannya program ini adalah untuk mendorong peningkatan kinerja perusahaan dalam hal pengelolaan lingkungan. Program ini mengimbau perusahaan untuk dapat memberikan transparansi informasi kepada para stakeholders mengenai aktivitas pengelolaan lingkungan oleh perusahaan.

Penilaian kinerja ketaatan perusahaan dalam PROPER menggunakan indikator warna, dimulai dari warna emas sebagai peringkat terbaik, diikuti warna hijau, biru, merah, dan untuk peringkat terburuk diindikasikan dengan warna hitam. Hal ini dimaksudkan untuk mempermudah masyarakat untuk mengetahui peringkat yang ada. Aspek penilaian dalam PROPER difokuskan pada penilaian ketaatan perusahaan dalam pengendalian pencemaran air, pengendalian pencemaran udara, pengelolaan limbah bahan berbahaya dan beracun (B3), kewajiban lain yang terkait dengan analisis mengenai dampak lingkungan (AMDAL), penetapan Sistem Manajemen Lingkungan (SML), konservasi dan pemanfaatan sumber daya, serta kegiatan sosial perusahaan.

\section{Pengembangan Hipotesis \\ Kepemilikan Manajerial}

Menurut teori keagenan, adanya kemungkinan permasalahan yang timbul diantara pemegang saham dan manajer disebabkan karena kecilnya kepemilikan oleh agen di perusahaan (Said, et al 2009). Hal ini dapat menjadi penyebab tindakan opportunis yang dilakukan oleh manajer. Rawi (2008) dan Murwaningsari (2009) menemukan adanya hubungan positif antara kepemilikan manajerial dengan pengungkapan CSR. Dengan adanya kepemilikan saham oleh manajemen, maka manajemen akan ikut serta aktif dalam pengambilan keputusan. Mereka akan memperoleh manfaat langsung atas keputusankeputusan yang diambilnya, namun juga akan menanggung resiko secara langsung bila keputusan itu salah. Manajer perusahaan akan mengambil keputusan sesuai dengan kepentingan perusahaan yaitu dengan cara mengungkapkan informasi sosial yang seluasluasnya dalam rangka untuk meningkatkan image perusahaan.

Dengan demikian, manajemen tidak akan bertindak yang akan merugikan perusahaan, sehingga dapat mengurangi agency cost. Berdasarkan penelitian tersebut, dapat diajukan hipotesis penelitian sebagai berikut:

\section{$\mathrm{H}_{1}$ : Kepemilikan manajerial berpengaruh} terhadap pengungkapan corporate social responsibility.

\section{Kepemilikan Institusional}

Kepemilikan oleh institusi dapat meningkatkan pengendalian terhadap manajemen dan mengurangi peluang tindak kecurangan yang mungkin dilakukan (Murwaningsari, 2009). Institusi secara profesional akan memantau perkembangan investasinya agar dapat menghasilkan keuntungan yang ingin dicapai. Monitoring yang dilakukan oleh institusi inilah yang akan menekan manajemen agar tidak bertindak menyimpang.

Menurut Murwaningsari (2009), investor institusional memiliki power dan experience untuk bertanggung jawab dalam menerapkan prinsip corporate governance untuk melindungi hak dan kepentingan seluruh pemegang saham, sehingga mereka menuntut perusahaan untuk melakukan komunikasi secara transparan. Berdasarkan hal tersebut, dapat diajukan hipotesis penelitian sebagai berikut: 
$\mathrm{H}_{2}$ : Kepemilikan institusional berpengaruh terhadap pengungkapan corporate social responsibility.

\section{Komite Audit}

Menurut KNKG (2006), salah satu tugas komite audit adalah untuk memastikan bahwa struktur pengendalian internal perusahaan dilakukan dengan baik. Adanya anggota independen dalam komite audit dapat menjadi alat yang efektif untuk melakukan mekanisme pengawasan sehingga dapat mengurangi biaya agensi, meningkatkan pengendalian internal dan akan meningkatkan kualitas pengungkapan informasi perusahaan (Said, et al, 2009). Anggota independen dapat secara objektif membantu dewan komisaris melaksanakan tugas pengawasan terhadap manajemen. Berdasarkan hal tersebut, dapat diajukan hipotesis penelitian sebagai berikut:

$\mathrm{H}_{3}$ : Komite audit berpengaruh terhadap pengungkapan corporate social responsibility.

\section{Ukuran Dewan Komisaris}

Berdasarkan teori agensi, dewan komisaris dianggap sebagai mekanisme pengendalian intern tertinggi, yang bertanggungjawab untuk memonitor tindakan manajemen puncak. Ukuran dewan komisaris dilihat dari jumlah anggotanya. Semakin besar jumlah anggota dewan komisaris, maka akan semakin mudah untuk mengendalikan CEO dan monitoring yang dilakukan akan semakin efektif (Coller dan Gregory, 1999 dalam Sembiring 2005). Dikaitkan dengan pengungkapan informasi oleh perusahaan, kebanyakan penelitian menunjukkan adanya hubungan positif antara berbagai karakteristik dewan komisaris dengan tingkat pengungkapan informasi oleh perusahaan.

Yuniarti (2003) dan Sembiring (2005) menyatakan hal yang sama bahwa ukuran dewan komisaris berpengaruh terhadap pengungkapan tanggung jawab sosial. Berdasarkan hal tersebut, dapat diajukan hipotesis penelitian sebagai berikut:

$\mathrm{H}_{4}$ : Ukuran dewan komisaris berpengaruh terhadap pengungkapan corporate social responsibility.

\section{Kinerja Lingkungan}

Menurut Verrecchia (1983), dalam Suratno et al, (2006) dengan discretionary disclosure teorinya mengatakan pelaku lingkungan yang baik percaya bahwa dengan mengungkapkan performance mereka berarti menggambarkan good news bagi pelaku pasar. Oleh karena itu, perusahaan dengan environmental performance yang baik perlu mengungkapkan informasi kuantitas dan mutu lingkungan yang lebih dibandingkan dengan perusahaan dengan environmental performance lebih buruk. Semakin banyak peran perusahaan dalam kegiatan lingkungannya, maka akan semakin banyak pula yang harus diungkapkan oleh perusahaan mengenai kinerja lingkungan yang dilakukannya dalam laporan tahunannya.

Hal ini melandasi penelitian oleh Rakhiemah dan Agustia (2012) yang menemukan hubungan positif signifikan antara kinerja lingkungan dengan pengungkapan CSR. Berdasarkan penelitian tersebut, dapat dirumuskan hipotesis sebagai berikut:

$\mathrm{H}_{5}$ : Kinerja lingkungan berpengaruh terhadap pengungkapan corporate social responsibility.

\section{Metode Penelitian}

\section{Jenis dan Obyek Penelitian}

Jenis penelitian yang dilakukan adalah penelitian kausatif. Penelitian kausatif merupakan penelitian yang menganalisis pengaruh antara variabel dependen dan variabel independen. Objek penelitian dari kasus ini adalah laporan tahunan perusahaan manufaktur yang terdaftar di Bursa Efek Indonesia (BEI). Menggunakan perusahaan manufaktur karena perusahaan tersebut merupakan perusahaan yang jumlahnya relative besar di Indonesia.

\section{Populasi dan Sampel Penelitian}

Populasi dalam penelitian ini adalah perusahaan manufaktur yang telah terdaftar di Bursa Efek Indonesia (BEI) tahun 2011-2015. Metode pengambilan sampel yang digunakan adalah purposive sampling dengan tujuan untuk mendapatkan sampel yang representatif sesuai dengan kriteria yang ditentukan. Kriteria pemilihan sampel sebagai berikut: (1) Perusahaan manufaktur yang terdaftar di Bursa Efek Indonesia selama periode 2011-2015, (2) Perusahaan manufaktur yang menerbitkan dan mempublikasikan laporan tahunan (апnиal report) secara berturut-turut selama periode 2011-2015, (3) Perusahaan manufaktur yang telah mengikuti PROPER selama periode 2011-2015, (4) Perusahaan manufaktur yang menyajikan informasi lengkap yang 
dibutuhkan dalam penelitian selama periode 20112015.

\section{Jenis Data dan Sumber Data}

Jenis data yang digunakan dalam penelitian ini adalah data sekunder. Sumber data sekunder yaitu sumber data penelitan yang diperoleh secara tidak langsung atau melalui media perantara (diperoleh dan dicatat oleh pihak lain). Data variabel kinerja lingkungan menggunakan data laporan PROPER yang diambil dari website www.menlh.co.id. Sedangkan data untuk variabel good corporate governance dan pengungkapan corporate social responsibility menggunakan annual report perusahaan diambil dari website www.idx.co.id.

\section{Variabel Independen \\ Kepemilikan Manajerial}

Kepemilikan saham merupakan salah satu hal yang sangat penting dan mampu mempengaruhi pengambilan keputusan dalam sebuah perusahaan. Kepemilikan saham manajerial adalah tingkat kepemilikan saham pihak manajemen yang secara aktif ikut dalam pengambilan keputusan. Kepemilikan manajerial diukur dengan menghitung presentase jumlah lembar saham yang dimiliki pihak manajemen yaitu manajer, komisaris terafiliasi (diluar komisaris independen) dan direksi dibagi dengan total jumlah lembar saham yang beredar.

$$
K M=\frac{\text { jumlah saham yang dimiliki manajemen }}{\text { jumlah saham yang beredar }}
$$

\section{Kepemilikan Institusional}

Kepemilikan saham institusional merupakan kepemilikan saham yang dimiliki oleh investor institusional. Investor institusional mencakup bank, dana pensiun, perusahaan asuransi, perseroan terbatas dan lembaga keuangan lainnya. Kepemilikan institusional dinyatakan dalam presentase yang diukur dengan cara membandingkan jumlah lembar saham yang dimiliki oleh investor institusional dibanding dengan total jumlah lembar saham yang beredar.

$K I=\frac{\text { jumlah saham yang dimiliki institusi }}{\text { jumlah saham yang beredar }}$

\section{Komite Audit}

Komite audit berperan penting dalam meningkatkan standar tata kelola perusahaan. Komite audit merupakan komite yang dibentuk oleh dewan komisaris, yang bertugas untuk membantu dewan komisaris dalam melaksanakan tugasnya. Salah satu fungsi komite audit sebagai bagian dalam perusahaan adalah membantu dewan komisaris memastikan struktur pengendalian internal sudah cukup dan efektif. Komite audit diukur dengan cara menghitung banyaknya anggota komite audit dalam perusahaan.

\section{$K A=$ jumlah seluruh anggota komite audit}

\section{Ukuran Dewan Komisaris}

Ukuran dewan komisaris dilihat dari jumlah anggota dewan komisaris yang terdapat pada perusahaan. Pengukuran dalam penelitian ini refleksi dengan penilitian yang dilakukan oleh Serimbing (2005) yaitu dilihat dari banyaknya jumlah anggota dewan komisaris perusahaan.

$U D K=$ jumlah seluruh anggota dewan komisaris

\section{Kinerja Lingkungan}

Kinerja lingkungan ini diukur dari prestasi perusahaan mengikuti PROPER yang merupakan salah satu upaya yang dilakukan oleh Kementrian Lingkungan Hidup (KLH) untuk mendorong penataan perusahaan dalam pengelolaan lingkungan hidup melalui instrumen informasi. Sistem peringkat kinerja PROPER mencakup pemeringkatan perusahaan dalam lima (5) warna yakni: (1) Emas = Sangat sangat baik, skor 5, (2) Hijau = Sangat baik, skor 4, (3) Biru = Baik, skor 3, (4) Merah = Buruk, skor 2, dan (5) Hitam= Sangat buruk, skor 1 .

\section{Variabel Dependen}

\section{Pengungkapan Corporate Social Responsibility}

Variabel dependen yang digunakan dalam penelitian ini adalah pengungkapan corporate social responsibility yang dilihat dari annual report perusahaan manufaktur yang terdaftar di Bursa Efek Indonesia. Pengungkapan tanggun jawab sosial perusahaan dalam laporan tahunan ini diukur dengan membandingkan jumlah pengungkapan yang dilakukan perusahaan dengan jumlah pengungkapan yang disyaratkan dalam Global Reporting Initiative (GRI) Generasi Ketiga (G3) yang meliputi 149 item pengungkapan yaitu: Strategi dan Analisa, Profil Organisasi, Identifikasi Aspek Material dan Batas, Stakeholder Engagement, Profil, Tata kelola Organisasi, Etika dan Integritas, Ekonomi, Lingkungan Hidup, dan Sosial yang Mencakup Hak Asasi Manusia, Praktik Ketenagakerjaan, Tanggung Jawab Produk, dan Kemasyarakatan.

Metode yang digunakan untuk mengukur indeks yang telah dibentuk tersebut adalah dengan cara 
content analysis yaitu nilai 1 untuk setiap item yang diungkapkan serta 0 untuk item yang tidak diungkapkan dalam kategori-kategori yang telah ditentukan Global Reporting Initiative (GRI). Perhitungan indeks pengungkapan tanggung jawab sosial perusahaan pada laporan tahunan menggunakan rumus sebagai berikut:

$$
\operatorname{CSDI}_{\mathrm{j}}=\frac{\Sigma \mathrm{X}_{\mathrm{ij}}}{n_{\mathrm{j}}}
$$

Keterangan:

$$
\begin{array}{ll}
\mathrm{CSDI} \square & =\text { Corporate Social Disclosure Index } \\
& \text { perusahaan } \mathrm{j} \\
\mathrm{n} \square & =\text { jumlah item yang harus diungkapkan, } \mathrm{n} \square \\
& =149 \\
\mathrm{X}_{\mathrm{i}} \square \quad & =\text { jumlah item yang diungkapkan, } 1=\text { jika } \\
& \text { item i diungkapkan; } 0=\text { jika item i tidak } \\
& \text { diungkapkan. }
\end{array}
$$

\section{Metode Analisis Data}

Metode analisis data yang digunakan dalam penelitian ini adalah regresi berganda. Karena dalam analisis regresi, selain mengukur kekuatan hubungan antara dua variabel atau lebih, juga menunjukan arah hubungan antara variabel dependen dengan variabel independen (Ghozali, 2009). Analisis regresi berganda dalam penelitian ini digunakan untuk menguji pengaruh variabel independen yaitu kepemilikan manajerial, kepemilikan institusional, independensi komite audit, independensi ukuran dewan komisaris, kinerja lingkungan terhadap variabel dependen pengungkapan corporate social responsibility.

\section{Hasil dan Pembahasan}

\section{Deskripsi Obyek Penelitian}

Objek penelitian dari kasus ini adalah laporan tahunan (annual report) perusahaan manufaktur yang terdaftar di Bursa Efek Indonesia (BEI). Jenis data yang digunakan dalam penelitian ini

\begin{tabular}{|c|c|}
\hline Kriteria & Jumlah \\
\hline $\begin{array}{l}\text { Perusahaan manufaktur yang terdaftar } \\
\text { di BEI selama periode } 2011-2015\end{array}$ & 143 \\
\hline $\begin{array}{l}\text { Perusahaan manufaktur yang tidak } \\
\text { menerbitkan annual report secara } \\
\text { berturut-turut selama periode 2011- } \\
2015\end{array}$ & $(35)$ \\
\hline $\begin{array}{l}\text { Perusahaan manufaktur yang tidak } \\
\text { mengikuti PROPER selama periode } \\
2011-2015\end{array}$ & (79) \\
\hline $\begin{array}{l}\text { Perusahaan manufaktur yang tidak } \\
\text { menyajikan informasi lengkap selama } \\
\text { periode 2011-2015. }\end{array}$ & (5) \\
\hline $\begin{array}{l}\text { Tersedia data lengkap sesuai kriteria } \\
\text { penelitian }\end{array}$ & 24 \\
\hline $\begin{array}{l}\text { Jumlah sampel diolah } 24 \times 5 \text { tahun } \\
\text { penelitian }\end{array}$ & 120 \\
\hline Terdapat data Outlier & (7) \\
\hline
\end{tabular}
adalah data sekunder. Pemilihan sampel dalam penelitian ini ditentukan dengan menggunakan metode purposive sampling dengan beberapa kriteria pengambilan sampel. Pengambilan sampel penelitian ini digambarkan pada tabel di bawah ini:
Tabel IV.1

Sampel Penelitian Tahun 2011-2015

Sumber: Data sekunder diolah, 2017

\section{Analisis Statistik Deskriptif}

Statistik deskriptif ini merupakan pengujian statistik yang digunakan untuk mengetahui gambaran umum data penelitian. Berikut hasil uji statistik deskriptif yang dapat dilihat dari nilai rata-rata (mean), standar deviasi, maksimum dan minimum dan secara ringkas ditunjukan pada tabel berikut:

Tabel IV.2

Statistik Deskriptif

\begin{tabular}{lrrrr}
\hline Variabel & Min & Maks & Rata-rata & $\begin{array}{c}\text { Std. } \\
\text { Deviasi }\end{array}$ \\
\hline KM & 0,00 & 0,18 & 0,0217 & 0,05080 \\
KI & 0,58 & 1,00 & 0,9552 & 0,09767 \\
KA & 2 & 4 & 3,07 & 0,395 \\
UDK & 2 & 9 & 5,11 & 1,882 \\
KL & 2 & 5 & 3,27 & 0,710 \\
PCSR & 0,208 & 0,477 & 0,31335 & 0,050883
\end{tabular}

Sumber: Data sekunder diolah, 2017

\section{Uji Analisis Regresi Linier Berganda}

Analisis regresi linier berganda digunakan untuk membuktikan pengaruh variabel independen terhadap variabel dependen. Dapat ditunjukan hasil rangkuman analisis regresi linear berganda seperti pada tabel berikut: 
Tabel IV.7

Analisis Regresi Linier Berganda

\begin{tabular}{lccc}
\hline \multicolumn{1}{c}{ Variabel } & B & $\begin{array}{c}\text { Std. } \\
\text { Error }\end{array}$ & Sig. \\
\hline Konstan & 0,394 & 0,075 & 0,000 \\
KM & $-0,247$ & 0,097 & 0,013 \\
KI & $-0,195$ & 0,051 & 0,000 \\
KA & 0,023 & 0,012 & 0,059 \\
UDK & 0,002 & 0,003 & 0,369 \\
KL & 0,009 & 0,006 & 0,160 \\
Adj. $\mathrm{R}^{2}=0,261 \mathrm{~F}_{\text {hitung }}=8,894$ Sig $=0,000$ & \\
$\mathrm{t}_{\text {tabel }}=1,982$ & $\mathrm{~F}_{\text {tabel }}=2,30$ p value $=0,05$ \\
Sumber
\end{tabular}

Sumber: Data sekunder diolah, 2017

Pada penelitian ini menggunakan model persamaan regresi linier berganda yaitu, sebagai berikut:

PCSR $=0,394-0,247 \mathrm{KM}-0,195 \mathrm{KI}+0,023 \mathrm{KA}+$ 0,002UDK + 0,009KI + e

\section{Uji Hipotesis}

\section{Uji Signifikansi Simultan (Uji Statistik f)}

Hasil pengujian hipotesis secara serentak diperoleh nilai $F_{\text {hitung }}$ sebesar $8,894>$ dari nilai $F_{\text {tabel }}$ sebesar 2,30 dengan nilai signifikan $0,000<\alpha=0,05$ sehingga dapat disimpulkan kepemilikan manajerial, kepemilikan institusional, komite audit, ukuran dewan komisaris, dan kinerja lingkungan berpengaruh secara bersama-sama terhadap pengungkapan corporate social responsibility. Hal ini juga bisa diartikan bahwa model regresi yang digunakan sudah sesuai (fit) dengan datanya.

\section{Uji Parsial (Uji t)}

Hasil pengujian uji $t$ untuk variabel kepemilikan manajerial diperoleh $\mathrm{t}_{\text {hitung }}$ sebesar $-2,538$ $<t_{\text {tabel }}$ sebesar -1,982 dengan $p$-value tingkat signifikansi sebesar $0,013<0,05$, sehingga hipotesis diterima, akan tetapi terdapat pengaruh negatif. Dari hasil pengujian uji $\mathrm{t}$ untuk variabel kepemilikan institusional diperoleh $t_{\text {hitung }}$ sebesar $-3,797<t_{\text {tabel }}$ sebesar -1,982 dengan $p$-value tingkat signifikansi sebesar $0,000<0,05$, sehingga hipotesis diterima, akan tetapi terdapat pengaruh negatif.

Dari hasil pengujian uji $t$ untuk variabel komite audit diperoleh $t_{\text {hitung }}$ sebesar 1,912 $<t_{\text {tabel }}$ sebesar 1,982 dengan $p$-value tingkat signifikansi sebesar $0,059>0,05$, sehingga hipotesis ditolak. Dari hasil pengujian uji t untuk variabel ukuran dewan komisaris diperoleh $\mathrm{t}_{\text {hitung }}$ sebesar $0,902<\mathrm{t}_{\text {tabel }}$ sebesar 1,982 dengan $p$-value tingkat signifikansi sebesar $0,369>$ 0,05 , sehingga hipotesis ditolak. Dari hasil pengujian uji $t$ untuk variabel kinerja lingkungan diperoleh $t_{\text {hitung }}$ sebesar $1,416<\mathrm{t}_{\text {tabel }}$ sebesar 1,982 dengan $p$-value tingkat signifikansi sebesar $0,160>0,05$, sehingga hipotesis ditolak.

\section{Pembahasan}

\section{Pengaruh Kepemilikan Manajerial terhadap} Pengungkapan Corporate Social Responsibility

Berdasarkan hasil pengujian hipotesis, variabel kepemilikan manajerial memiliki nilai signifikansi sebesar $0,013<0,05$. Hal ini menunjukkan bahwa kepemilikan manajerial berpengaruh terhadap pengungkapan corporate social responsibility, akan tetapi pengaruhnya negatif, sehingga semakin besar persentase kepemilikan manajerial dalam perusahaan mengakibatkan pengungkapan $C S R$ semakin rendah. Hal ini disebabkan karena kepemilikan manajerial yang tingkatnya tinggi lebih memfokuskan pada pengembangan tingkat kemampuan kerja perusahaannya dan pandangan investor manajerial yang bersifat mencari laba dapat menyebabkan tidak terdorongnya kebijakan perusahaan yang bersifat nilai tambah seperti pengungkapan tanggungjawab sosial perusahaan.

Hasil penelitian ini sesuai dengan penelitian yang dilakukan oleh Ginting (2016) yang menyatakan bahwa peningkatan kepemilikan manajerial mengakibatkan penurunan pengungkapan CSR oleh perusahaan. Namun hasil ini bertentangan dengan penelitian yang dilakukan oleh Sari dan Rani (2015) yang menunjukkan kepemilikan manajerial secara parsial tidak berpengaruh terhadap pengungkapan corporate social responsibility.

\section{Pengaruh Kepemilikan Institusional terhadap Pengungkapan Corporate Social Responsibility}

Berdasarkan hasil pengujian hipotesis, variabel kepemilikan institusional memiliki nilai signifikansi sebesar $0,000<0,05$. Hal ini menunjukkan bahwa kepemilikan institusional berpengaruh terhadap pengungkapan corporate social responsibility, akan tetapi pengaruhnya negatif. Hasil penelitian ini diketahui kepemilikan institusional berpengaruh terhadap pengungkapan corporate social responsibility dengan arah negatif. Yang disebabkan karena fokus dari kepemilikan institusional adalah mencari laba yang akan berdampak langsung pada tingkat 
pengembalian yang diperoleh pemilik institusi dari investasinya di perusahaan. Dengan demikian, semakin besar kepemilikan institusional, tuntutan perusahaan untuk menghasilkan laba akan semakin besar sehingga perusahaan terdorong untuk melakukan efisiensi biaya termasuk biaya yang dikeluarkan perusahaan untuk aktivitas tanggung jawab sosialnya (Sari dan Rani, 2015).

Hasil penelitian ini berbeda dengan penelitian Priantana dan Yustian (2011) yang menunjukkan bahwa investasi oleh pihak institusi pada perusahaan tidak mempengaruhi keputusan perusahaan untuk melakukan tanggung jawab sosial perusahaan. Namun, hasil penelitian ini sesuai dengan penelitian yang dilakukan oleh Ramdhaningsih dan Utama (2013), serta Sari dan Rani (2015) yang menemukan adanya hubungan negatif antara kepemilikan saham institusional dengan pengungkapan CSR.

Pengaruh Komite Audit terhadap Pengungkapan Corporate Social Responsibility

Berdasarkan hasil pengujian hipotesis, variabel komite audit memiliki nilai signifikansi sebesar 0,059 $>0,05$. Hal ini menunjukkan bahwa komite audit tidak berpengaruh terhadap pengungkapan corporate social responsibility. Komite audit dalam perusahaan tidak berpengaruh terhadap pengungkapan $C S R$, disebabkan karena fungsi pengawasan yang dijalankan perusahaan kurang maksimal, karena komite audit mempunyai tugas untuk membantu komisaris atau dewan pengawas dalam pelaksanaan transparansi perusahaan, sehingga faktor tekanan maupun kepentingan sepihak menjadikan komite audit berkerja di bawah tekanan.

Hasil penelitian ini sesuai dengan penelitian yang dilakukan oleh Priantana dan Yustian (2011), serta Ginting (2016) yang menyatakan bahwa komite audit tidak berpengaruh terhadap pengungkapan corporate social responsibility.

Pengaruh Ukuran Dewan Komisaris terhadap Pengungkapan Corporate Social Responsibility

Berdasarkan hasil pengujian hipotesis, variabel ukuran dewan komisaris memiliki nilai signifikansi sebesar 0,369>0,05. Hal ini menunjukkan bahwa ukuran dewan komisaris tidak berpengaruh terhadap pengungkapan corporate social responsibility. Ukuran dewan komisaris yang rata-rata kecil, maka akan mengakibatkan semakin sulit untuk mengendalikan CEO dan memonitoringnya, sehingga yang dilakukan akan kurang efektif.
Hasil penelitian ini sesuai dengan penelitian yang dilakukan oleh Ramdhaningsih dan Utama (2013), serta Wijaya (2012) yang menyatakan bahwa ukuran dewan komisaris tidak berpengaruh terhadap pengungkapan corporate social responsibility. Namun berbeda dengan penelitian yang dilakukan oleh Priantana dan Yustian (2011) bahwa ukuran dewan komisaris berpengaruh signifikan terhadap pengungkapan $C S R$, yang berarti bahwa semakin banyak jumlah anggota dewan komiaris dalam suatu perusahaan, pengungkapan $C S R$ perusahaan akan semakin luas.

Pengaruh Kinerja Lingkungan terhadap Pengungkapan Corporate Social Responsibility

Berdasarkan hasil pengujian hipotesis, variabel kinerja lingkungan memiliki nilai signifikansi sebesar $0,160>0,05$. Hal ini menunjukkan bahwa kinerja lingkungan yang diukur dengan peringkat PROPER tidak berpengaruh signifikan terhadap pengungkapan corporate social responsibility. Alasan ditolaknya hipotesis ini dikarenakan pengungkapan tanggung jawab sosial yang diungkapkan perusahaan sampel yang telah mengikuti PROPER oleh Kementrian Lingkungan Hidup ini tidak banyak diungkapkan dilaporan tahunan.

Hasil penelitian ini sesuai dengan penelitian yang dilakukan oleh Wijaya (2012) yang menyatakan bahwa kinerja lingkungan tidak berpengaruh terhadap pengungkapan corporate social responsibility. Namun berbeda dengan penelitian yang dilakukan oleh Rakhiemah dan Agustia (2012) yang mengatakan bahwa kinerja lingkungan berpengaruh signifikan terhadap pengungkapan $C S R$.

\section{Simpulan}

Berdasarkan analisis yang telah dilakukan dalam penelitian ini, menyimpulkan bahwa secara parsial, kepemilikan manajerial dan kepemilikan institusional berpengaruh terhadap pengungkapan corporate social responsibility, akan tetapi berpengaruh negatif. Sedangkan komite audit, ukuran dewan komisaris dan kinerja lingkungan tidak berpengaruh terhadap pengungkapan corporate social responsibility.

\section{Keterbatasan Penelitian}

Penelitian ini hanya menggunakan beberapa variabel independen sehingga hasil penelitian ini belum maksimal untuk menjelaskan variasi terhadap 
variabel dependen. Penelitian ini hanya menggunakan data sekunder laporan keuangan tahunan dari perusahaan manufaktur yang didapatkan dari BEI dan belum dapat digeneralisasikan kepada populasi yang lebih luas.

Saran

Penelitian selanjutnya disarankan dapat menambah variabel independen lainnya yang diduga mampu menjelaskan secara maksimal variasi terhadap variabel dependen serta menambahkan model variabel moderasi maupun mediasi. Penelitian selanjutnya diharapkan tidak hanya menggunakan data sekunder laporan keuangan dari perusahaan manufaktur sebagai objek penelitian serta dengan jumlah sampel yang lebih luas sehingga penelitian dapat lebih digeneralisasi.

\section{Referensi}

[1] Daniri, M, A., 2007. Standarisasi Tanggung Jawab Sosial Perusahaan. www.madhani-ri.com. Diakses 17 September 2016 puku 15.45 WIB.

[2] Deegan, Craig. 2000. Financial Accounting Theory. McGraw-Hil, Australia Pty Limited.

[3] FCGI. Forum for Corporate Governance in Indonesia. Www.fcgi.or.id. Diakses 19 September 2016 pukul 14.30 WIB.

[4] Ghozali, I \& Chariri, A .2007. Teori Akuntansi. Semarang. Badan Penerbit UNDIP.

[5] Ginting, Y. L. (2016). Mekanisme Tata Kelola dan Pengungkapan Tanggung Jawab Sosial Perusahaan. Jurnal Ekonomi dan Manajemen, 13.

[6] GRI. 2013. Global Reporting Initiative: Sustainability Reporting Guidelines. www.globalreporting.org. Diakses 2 Agustus 2016 pukul 14.09 WIB.

[7] Ikatan Akuntan Indonesia. 2004. Pernyataan Standar Akuntansi Keuangan (PSAK). No. 1. Jakarta.

[8] Jensen, Michael C dan Meckling, William H. 1976. "Theory of The Firm: Managerial Behavio, Agency Cost and Ownership Structure." Journal of Financial Economic, Vol. 3 No. 4, pp. 305-360.

[9] KNKG. (2006). Komite Nasional Kebijakan Governance. Pedoman umum Good Corporate Governance Indonesia, 5-15.

[10] Murwaningsari, E., 2009. Hubungan Corporate Governance, Corporate Social Responsibility dan
Corporate Financial Performance Dalam Satu Continum. Jurnal Akuntansi dan Keuangan. Vol. 11, No. 1, hal 30-41.

[11] Priantana, R. D., \& Yustian, A. (2011). Pengaruh Struktur Good Corporate Governance Terhadap Pengungkapan Corporate Social Responsibility Pada Perusahaan Keuangan Yang Terdaftar di Bursa Efek Indonesia. Jurnal Telaah \& Riset Akuntansi, 65-78.

[12] PROPER. Program Penilaian Peringkat Kinerja Perusahaan dalam Pengelolaan Lingkungan. www.menlh.co.id. Diakses 5 Agustus 2016 pukul 11.20 WIB.

[13] Rakhiemah, A. N., \& Agustia, D. (2012). Pengaruh Kinerja Lingkungan Terhadap Corporate Social Responsibility (CSR) Disclosure dan Kinerja Finansial Perusahaan Manufaktur Yang Terdaftar di Bursa Efek Indonesia. 1-31.

[14] Ramdhaningsih, A., \& Utama, I. M. (2013). Pengaruh Indikator Good Corporate Governance dan Profitabilitas Pada Pengungkapan Corporate Social Responsibility. E-Jurnal Akuntansi Universitas Udayana, 65-82.

[15] Ratnasari,Y., \& Andri Prastiwi, S.E., M.Si., Akt. 2010. Pengaruh Corporate Governance Terhadap Luas Pengungkapan Tanggung Jawab Sosial Perusahaan Di Dalam Sustainable Report. Thesis. Fakultas Ekonomi. Universitas Diponegoro. Semarang.

[16] Rawi, 2008, Pengaruh Kepemilikan manajemen, Institusi, dan Leverage Terhadap Corporate Social Responsibility Pada Perusahaan Manufaktur yang Listing di Bursa Efek Indonesia. Thesis. Universitas Diponegoro, Semarang.

[17] Rustiarini, Ni Wayan. 2011. Pengaruh Struktur Kepemilikan Saham Pada Pengungkapan Corporate Social Responsibility. Universitas Mahasaraswati Denpasar.

[18] Said, et, al. 2009. The Relationship between Corporate Social Responsibility and Corporate Governance Characteristics in Malaysian Public Listed Companies. Social Responsibility Journal. Vol. 5, No. 2, hal. 212-226.

[19] Sari, W. N., \& Rani, P. (2015). Pengaruh Kepemilikan Institusional, Kepemilikan Manajerial, Return on Assets (ROA) dan Ukuran Perusahaan Terhadap Pengungkapan Corporate 
Social Responsibility (CSR) Pada Perusahaan Manufaktur Yang Terdaftar di Bursa Efek Indonesia Periode 2011-2013. Jurnal Akuntansi dan Keuangan, 4.

[20] Sembiring, E, R., (2005). Karakteristik Perusahaan dan Pengungkapan Tanggung Jawab Sosial: Study Empiris Pada Perusahaan yang Tercatat di Bursa Efek Jakarta. Simposium Nasional Akuntansi VIII Solo. 379-395.

[21] Suratno, Ignatius Bondan, dkk. 2006. Pengaruh Environmental Performance terhadap Environmental Disclosure dan Economic Performance (Studi Empiris Pada Perusahaan Manufaktur yang Terdaftar di Bursa Efek Jakarta Periode 2001-2004). Simposium Nasional Akuntansi 9. Padang.

[22] Suwardjono. (2005). Teori Akuntansi: Perekayasaan Pelaporan Keuangan (3 ed.). Yogyakarta: BPFE.

[23] TAP MPR No. II/MPR/1998 Tentang GBHN. www.bapepam.go.id. Diakses 2 September 2016 pukul 14.50 WIB

[24] Wardhani, D. G., \& Sugiharto, T. (2013). Pengaruh Kinerja Keuangan, Ukuran Perusahaan, dan Kinerja Lingkunga Terhadap Intensitas Pengungkapan Pelaksanaan Tanggung Jawab Sosial Perusahaan Manufaktur Yang Terdaftar di Bursa Efek Indonesia. Proceeding PESAT (Psikologi, Ekonomi, Sastra, Arsitektur \& Teknik Sipil), 128-139.

[25] Wijaya, M. (2012). Faktor-faktor Yang Mempengaruhi Pengungkapan Tanggung Jawab Sosial Pada Perusahaan Manufaktur Yang Terdaftar di Bursa Efek Indonesia. Jurnal Ilmiah Mahasiswa Akuntansi, 1, 26-30.

[26] Yuniarti, E., (2003). Pengungkapan Informasi Pertanggungjawaban Sosial pada Perusahaan yang Terdaftar di BEJ. Jurnal Telaah \& Riset Akuntansi. 240-250.Fakultas Ekonomi Universitas Sriwijaya. 